\title{
Sigurnost okoliša - između aktivizma i sekuritizacije
}

\author{
Dario Malnar
}

Zagreb, Hrvatska

e-mail: malnar.zg@gmail.com

\section{Vedran Matošić}

\author{
Zagreb, Hrvatska \\ e-mail: vedranmatosic@gmail.com
}

\begin{abstract}
SAŽETAK Nakon završetka Hladnog rata pristupi proučavanju i definiranju pojma sigurnosti počinju se ubrzano mijenjati. Među teoretičarima prevladava mišljenje kako danas govorimo o sigurnosti kao dinamičnom društvenom procesu, pa su i prijetnje sigurnosti raznovrsne, ne više nužno određene isključivo vojnom prijetnjom državnoj suverenosti. Definiranje sigurnosne prijetnje ovisi o vremenu i prostoru, a jedan od najznačajnijih doprinosa suvremenom proučavanju fenomena sigurnosti pripada Kopenhaškoj školi. Buzan, Waever i suradnici etablirali su teoriju sekuritizacije i desekuritizacije kao instrumentarij označavanja suvremenih prijetnji sigurnosti koju valja promatrati u kontekstu suvremenog liberalizma. Sekuritizacija određenu pojavu definira kao prijetnju i premješta je u sferu takozvanog hitnog djelovanja, što je prema kritičarima Kopenhaške škole i njezin najveći nedostatak budući da takvo postupanje nosi opasnost od narušavanja demokratskih standarda. Stoga se teorijom desekuritizacije nastoji otkloniti potencijalno ugrožavanje demokratskog procesa. Naime hitne mjere mogu biti otklonjene i bez javne rasprave te se problem stavlja na stol političkih institucija, naravno, ukoliko su argumenti koji govore u prilog odustajanju od hitnih mjera dovoljno uvjerljivi. Može se ustvrditi kako je država i dalje dominantni akter u definiranju određenog problema kao prijetnje sigurnosti, ali nipošto jedini. Kada je riječ o pitanjima ugrožavanja okoliša, civilno se društvo afirmiralo kao vjerodostojan korektiv državnim institucijama. Međutim i nevladine organizacije koje se bave pitanjima okoliša nisu jedinstvene kada je riječ o strategijama djelovanja i načinu postizanja određenih političkih ciljeva, bilo da je riječ o onima koje su aktivne na nacionalnoj bilo na globalnoj razini.
\end{abstract}

Ključne riječi: sigurnost okoliša, sekuritizacija, desekuritizacija, aktivizam, država, civilno društvo. 


\section{Uvod}

U razvijenim ustavnim demokracijama uobičajeno je javno sučeljavanje stajališta o pitanjima ugrožavanja nacionalne sigurnosti, međutim kako je neosporno riječ o dinamičnom društvenom procesu, shvaćanja i definicije sigurnosti mijenjaju se s obzirom na izazove. Danas se i pristaše konvencionalnih pristupa u tumačenju sigurnosti, fokusiranim na vojne prijetnje, slažu u stavu da prijetnje nisu trajno određene, već ovise o vremenu i prostoru u kojem se javljaju i definiraju. Aktiviranje institucionalnih sigurnosnih mehanizama generira stoga određenu društvenu napetost, bez obzira na to radi li se o terorističkoj prijetnji, ilegalnim migracijama, prirodnim katastrofama i epidemijama ili uništavanju okoliša. Obrana zahtijeva visok stupanj društvene mobilizacije i trenutačno djelovanje kako bi se uspostavilo zadovoljavajuće stanje sigurnosti. Pitanje prevencije ili očuvanja sigurnosti podrazumijeva primjenu mjera koje izlaze iz okvira „normalne“ demokratske procedure. Daljnje djelovanje ovisi o tome kako se sigurnosni problem javno interpretira budući da jednom stvorena napetost u kratkom vremenu može lako prerasti u kontraproduktivno panično stanje koje može paralizirati relevantne društvene aktere. Stoga je nužno u javnoj sferi jasno naznačiti što te mjere točno podrazumijevaju (Trombetta, 2007.:1).

Proučavanjem svih parametara nužnih za stabilnost i sigurnost države, drugih zajednica, pa i pojedinaca uobičajeno se nastoji, između ostalog, odgovoriti na pitanje je li uopće moguće postići zadovoljavajući stupanj sigurnosti. Tradicionalisti govore o potrebi jačanja kontrolnih mehanizama budući da prijetnje uvijek mogu iznenada stvoriti potrebu za uspostavom izvanrednih mjera. Ovom pristupu imanentno je jačanje državnih mehanizama. Bez snažne države, mišljenja su tradicionalisti (realisti i institucionalisti), ne može se postići zadovoljavajući stupanj sigurnosti. Liberalna škola mišljenja kritizira takvo stajalište tvrdeći da se na taj način samo potiču latentni međudržavni antagonizmi, a rizici od otvorenih sukoba postaju izgledniji. Liberali zagovaraju model kolektivne sigurnosti, što je moguće postići jedino demokratskim dijalogom i međudržavnom suradnjom. Liberali tako zahtijevaju „širenje“ pojma sigurnosti s osloncem na konstruktivističke i poststrukturalističke teorije nastojeći smanjiti ili čak potpuno napustiti klasične modele definiranja sigurnosti (Hansen, 2012.).

Ovaj rad bavi se razvojem rasprava o sigurnosti okoliša, procesom sekuritizacije u ustavnim demokracijama, gdje je država još uvijek dominantni subjekt u označavanju sigurnosnih prijetnji, te aktivizmom nevladinih organizacija koje su, posebice u zadnjem desetljeću, postale relevantan društveni subjekt koji određene pojave nastoji u javnom diskursu smjestiti u sferu ostvarivanja ili zaštite sigurnosti. Cilj ovoga rada pokazati je kako u ustavnim demokracijama država zadržava ulogu dominantnog aktera sekuritizacije određenih pitanja, pa tako i zaštitite okoliša, uz sve značajniju ulogu nevladinih organizacija, koje značajno doprinose participaciji građana u nastojanju da utječu na pitanja zaštite okoliša i time postaju korektiv manjkavosti predstavničke demokracije. Međutim, s obzirom na njihovu današnju raznorodnost, neke od njih mogu se pokazati i kao zapreka ekonomskom napredovanju. Teorije Kopenhaške škole, unatoč određenim manjkavostima i nedoumicama, na empirijskoj razini pružaju zadovoljavajući instrumentarij za označavanje sigurnosnog rizika. 
Kada govorimo o teoriji sekuritizacije nastaloj pod okriljem Kopenhaške škole, valja naglasiti kako njezini predstavnici ističu da ne postoji sigurnosni problem per se, već insistiraju na sigurnosnoj analizi, nakon čega slijedi potraga za rješenjem. Kada je problem jednom definiran kao - sigurnosni - tada se zahtijeva hitno djelovanje, što znači brzo donošenje odluka o prihvatljivom rješenju. Kritičari ovakvog pristupa ističu kako takvo razumijevanje procesa može generirati zloupotrebe zbog „suspenzije“ demokratskog odlučivanja. Međutim problem može nastati već i tijekom prethodne faze, dok traje proces označavanja određenog problema kao sigurnosnog. Naime u današnjem vremenu taj pojam može postati „žrtvom“ preširokog tumačenja ugrožavanja sigurnosti.

\section{Sigurnosna kontekstualizacija okoliša u teoriji sekuritizacije $i$ desekuritizacije}

Okoliš se kao sigurnosno pitanje počinje sustavnije izučavati krajem osamdesetih godina prošlog stoljeća. Fokusiranje na sigurnost okoliša posljedica je promijenjenih međunarodnih političkih i sigurnosnih okolnosti krajem 80-ih i početkom 90-ih godina prošlog stoljeća. To je vrijeme kada dolazi do intenzivnijeg preispitivanja prevladavajućih teorija sigurnosti. Tada se počinje napuštati tradicionalni, realistički pristup, koji vojnu prijetnju uzima kao najrelevantniji sigurnosni izazov, a zaštitu države kao najviši cilj. Također dolazi do širenja teorijskih promišljanja sigurnosti, u čemu su se posebno istaknuli pripadnici Kopenhaške škole. U fokus interesa dolaze novi pojmovi kao što su vojna sigurnost, ekonomska sigurnost, politička sigurnost, societalna sigurnost te demografska sigurnost, sigurnost okoliša i dr.

Oblikuju se političke rasprave, medijska upozorenja te akademska istraživanja vezana uz sigurnost okoliša (Vilijams, 2012.:343). Richard Ullman u članku „Redefining Security“ naglašavao je kako razmišljanje o ugroženosti kvalitete života ljudi treba uključiti u rasprave o širenju pojma nevojne prijetnje (Ullman, 1983.). To je bio poticaj za precizniju razradu pojma nevojne prijetnje i onoga što on obuhvaća. Na Međunarodnoj konferenciji o razoružanju i razvoju Generalne skupštine UN-a u New Yorku 1987. godine nevojna prijetnja po prvi se puta, kao mogućnost ugrožavanja sigurnosti, pojavljuje u fokusu interesa međunarodne javnosti.

U afirmaciji zaštite okoliša kao sigurnosnog pitanja poseban je doprinos Roberta Kaplana, koji je definirao promjene u okolišu kao jedan od mogućih inicijatora sukoba u 21. stoljeću (Kaplan, 1994.:58). Kaplan se, kao i većina autora u razmatranju sigurnosti okoliša, bavio problemima globalnog zatopljenja, ozonskih rupa ili izumiranja prašuma. Nadalje, važno je istaknuti pristup N. R. Biswasa koji naglašava kako „se na umu mora imati i veza između promjena u okolišu i egzistencije ljudi na lokalnoj razini" (Biswas, 2011.:1). Naime lokalne zajednice i pojedinci u pitanjima ekoloških problema postaju aktivniji subjekti i nerijetko su u tome uspješniji nego sama država.

Nešto kasnije u UN-ovom Izvješću o ljudskom razvoju za 1990. godinu ekonomska kriza označena je kao sigurnosno pitanje (UN Human Development Report, 1990.). Tako na scenu dolazi nova, konstruktivistička, sigurnosna paradigma koja u znan- 
stvenim raspravama i praktičnom djelovanju uključuje - nerazvijenost, nedostatne uvjete razvoja, loše upravljanje i uništavanje prirodnih resursa. ${ }^{1}$

Danas zaštita okoliša predstavlja uvjet sigurnosti ne samo država nego i pojedinaca. Kada govorimo o modernom pristupu pitanjima ugrožavanja sigurnosti, konstruktivisti razlikuju dvije supkategorije netradicionalnog pristupa pitanjima sigurnosti. Širitel $j i$, koji povezuju okoliš s ekonomskim krizama i međunarodnim i međuetničkim konfliktima i Produbljivači, koji se bave pitanjima o tome čija je sigurnost u određenom trenutku ugrožena (Biswas, 2011.:3).

$\mathrm{Na}$ teorijskoj razini definira se nekoliko konceptualnih veza između degradacije okoliša i ugrožene sigurnosti. Ponajprije govorimo o degradaciji okoliša koja ugrožava živote ljudi, što samo po sebi predstavlja sigurnosni kontekst. Potom govorimo o degradaciji okoliša kao uzročniku konflikata, a konačno i o uništavanju sredstava za život koje ugrožava sigurnost više država ili regija.

Osim države, kao referentni objekti sigurnosti pojavljuju se razne društvene skupine i pojedinci. Mijenjaju se i odnosi dviju fundamentalnih dimenzija sigurnosti - fizičke i psihološke. Psihološke prijetnje - koje uvjetuju da se osjećamo sigurnima ili nesigurnima - često su vidljivije nego što je to slučaj kod fizičkih prijetnji i podložne su individualnim interpretacijama (Snow, 2007.:160-161). U modernom poimanju sigurnosti psihološka dimenzija dobiva prioritetni značaj. S razlikovanjem fizičkih i psiholoških prijetnji dolazi i do promjene u objektivnom i subjektivnom pristupu kod definiranja prijetnji.

Još je Wolfers naglašavao kako pristup sigurnosti može biti objektivan (postojanje stvarne prijetnje) i subjektivan (postojanje percepcije prijetnje) te da se poklapanje tih dvaju pristupa ni na koji način ne može osigurati (Wolfers, 1962.:151). Dakle subjektivna percepcija o tome što je prijetnja ne mora nužno značiti stvarno postojanje prijetnje. To je posebno važno kada se referentni objekt koji se štiti širi s države i na nedržavne entitete, uključujući i pojedince (buman security) ${ }^{2}$. Fokus istraživanja pomaknuo se s prijetnji na entitete koji se štite i sredstava koja se pri tome koriste. U tako proširenom konceptu propituje se i samo pitanje sigurnosti, tko je definira i kroz koji proces. Nametnulo se, dakle, pitanje sekuritizacije, subjekta sekuritizacije i referentnog objekta u odnosu prema kojem se cijeli proces odvija i promatra.

1 Šire o konstruktivističkom konceptu: Alexander Wendt, Anarchy is what States Make of it: The Social Construction of Power Politics International Organization, Vol. 46, No. 2 (Spring, 1992), str. 391-425. i Social Theory of International Politics, Cambridge University Press, 1999.; V. Kublakova, N. Greenwood Onuf i P. Kowert ed., International Relations In a Constructed World, M.E. Sharpe, New York, 1998.; J. D. Ruggie, Constructing the World Polity, Routlege, London, 1998.

2 Floyd (2007.) navodi kako je „temeljna ideja koncepta sigurnosti pojedinca da je pojedinac krajnja točka brige za sigurnost, pri čemu se sigurnost shvaća kao sloboda od oskudice i/ili sloboda od straha.", Rita Floyd, Human Security and the Copenhagen School's Securitization Aproach: Conceptualizing Human Security as a Securitizing Move, Human Security Journal, Vol. 5, Winter 2007, str. 40. 
Teorijski model sekuritizacije, odnosno proces transformacije određenih pitanja u sigurnosna pitanja Buzan i suradnici razvili su u okviru Kopenhaške škole kako bi proširili sadržaj pojma sigurnosti i definirali metodu razlikovanja procesa sekuritizacije od procesa politizacije te precizirali tko što može sekuritizirati i pod kojim uvjetima.

Zašto je važno razlučiti navedene procese i politička pitanja od onih sigurnosnih? Jedan od odgovora nude Buzan i suradnici (1998.) kada navode kako „specifična priroda sigurnosnih prijetnji opravdava upotrebu izvanrednih mjera. Pozivanje na sigurnost bilo je ključno za legitimiranje uporabe sile, odnosno za otvaranje prostora državi da mobilizira, odnosno poduzme posebne ovlasti u rješavanju egzistencijalnih prijetnji“ (Buzan, Waewer i de Wilde, 1998.:21). Problem je za Buzana i sur. (1998.) društveno definiran koncept, što Hough objašnjava na način da „ako ljudi, bez obzira jesu li vladini ministri ili privatne osobe, smatraju da određeni problem na neki način ugrožava njihov život i na njega reagiraju politički, tada to pitanje treba smatrati sigurnosnim problemom" (Hough, 2004.:9). Ovdje se nameće nekoliko pitanja. To su, prije svega, definiranje aktera koji sekuritizira određeno pitanje - securitizing actor, objekta čija je sigurnost ugrožena - referent object, ciljne grupacije kojoj se obraća, slušateljstva - audience i konačno same prijetnje, što se smatra prijetnjom u široko postavljenom sigurnosnom kontekstu.

Sekuritizacija je proces kojim ne mora nužno upravljati država. Buzan i suradnici (1998.) naglašavaju kako je „moguće da drugi društveni entiteti otvaraju pitanja [...] Sekuritizatori mogu biti vlada, politička elita, vojska i civilno društvo" (Collins, 2007.:113). Floyd i Croft (2010.) upozoravaju kako ,je vjerojatno da će identificiranje sekuritizatora različitih od države biti puno teže“. To objašnjavaju nedostatkom prihvaćenih odgovora na pitanja tko sve može biti uključen u sekuritizaciju te koji su relevantni dokumenti i institucije (Floyd i Croft, 2010.:18). Referentni objekti mogu biti različiti. Buzan i suradnici (1998.) govore o vojnom, političkom, ekonomskom, societalnom i okolišnom. Referentni objekti protežu se od države, suvereniteta, ponekad i državnih ideologija, pa do kolektivnih identiteta neovisnih od države, poput nacije ili religije (Buzan, Waewer i de Wilde, 1998.:22-23). Floyd uz to navodi kako „sukladno okviru Kopenhaške škole pojedinci mogu biti oboje, sekuritizatori i/ili referentni objekti sigurnosti“ (Floyd, 2007.:40).

„U sektoru zaštite okoliša, raspon mogućih referentnih objekata je vrlo velik, proteže se od relativno konkretnih kao što su opstanak pojedinih vrsta (tigrova, kitova, čovječanstva) ili staništa (kišnih šuma, jezera) do mnogo nejasnijih pitanja velikih razmjera kao što su održavanje planetarne klime i biosfere" (Buzan, Waewer i de Wilde, 1998.:22-23).

Konačno ostaje pitanje prijetnje, odnosno koja je temeljna pretpostavka sekuritizacije pojedinog pitanja, odnosno kako u široko postavljenom konceptu sigurnosti izbjeći da problematika sigurnosti ne dobije širinu u kojoj bi se izgubio smisao same sigurnosti. Predstavnici Kopenhaške škole tu pretpostavku postavljaju kroz zahtjev „da je problem predstavljen kao egzistencijalna prijetnja“ (Buzan, Waewer i de Wilde, 1998.:24). Dakle težište je na označavanju i jezičnom definiranju - govor- 
nom činu, a ne nužno stvarnom postojanju egzistencijalne prijetnje. Uz to, sukladno konceptu sekuritizacije kako su ga postavili Buzan i suradnici, svaki se problem može transformirati u egzistencijalni problem. Na taj se način prijetnja u potpunosti prenosi u, kako ga nazva Wolfers, sferu subjektivnog pristupa sigurnosti, odnosno psihološku dimenziju sigurnosti. Buzan i suradnici (1998.) pritom naglašavaju „da se egzistencijalna prijetnja može razumjeti samo u odnosu na specifičan karakter predmetnog referentnog objekta“ (Buzan, Waewer i de Wilde, 1998.:21).

Uz to, da bi došlo do sekuritizacije nekog pitanja, slušateljstvo mora prihvatiti argumentaciju sekuritizatora kako je određeni problem egzistencijalna prijetnja referentnom objektu te da mu je opstanak ugrožen i kako se u stvari radi o sigurnosnom pitanju. Sigurnost „u osnovi ne počiva ni na objektima niti na subjektima nego između subjekata“ (Buzan, Waewer i de Wilde, 1998.:31). „Sekuritizacija nije prerogativ sekuritizatora, nešto postaje sigurnosni problem zbog toga što je opravdano uključeno u sigurnosna promišljanja političke zajednice. " Zapravo, slušateljstvo sigurnosni argument prihvaća ili ne, te konačno potvrđuje proces sekuritizacije uspješnim i predmetno pitanje sekuritiziranim - dakle sigurnosnim pitanjem. Stoga se moramo složiti s Floyd i Croftom (2010.) kada tvrde da „slušateljstvo može biti različito u različitim političkim sustavima“. Slušateljstvo se ne podudara s državljanima ili populacijom demokratske zemlje, te je „definiranje slušateljstva zapravo presudno“ (Floyd i Croft, 2010.:19).

Ujedno, kao i prethodno pitanje, potrebno je definirati sigurnosno pitanje, odnosno prijetnju i tvrdnju/argumentaciju kako je nešto sigurnosno pitanje. Ideja Kopenhaške škole kako se kod sigurnosti radi o samodostatnosti ne ostavlja nikakav prostor za teoretiziranje o tome što sigurnosni problem stvarno jest, kao ni o tome što bi trebalo biti sekuritizirano. ${ }^{4}$ Budući da se težište stavlja na subjektivnu komponentu, objektivna komponenta posljedično ostaje zapostavljena. Zapostavljanje objektivne komponente otvara mogućnost zlouporabe samog procesa sekuritizacije. Zloupora-

3 U ovom radu političku zajednicu promatramo u sadržaju kako ga je definirao Sládeček (2001.-2002.), kao trajnu povezanost, sudjelovanje u zajedničkoj praksi i konstantnosti interesa pojedinaca, ali i važenje tih interesa u okvirima države, odnosno da artikulirani ciljevi pojedinaca konstituiraju javni interes putem obrazlaganja, rasprave, kritiziranja, demokratskog odlučivanja, političkih izbora itd. Politička zajednica pri tome podrazumijeva „jaču“ povezanost građana od udruženja, tj. asocijacije: osim poštovanja zakona, odnosno potpadanja pod jedinstvenu legislativu, građani dijele i „svijet zajedničkih značenja“.

Ovako određena, politička zajednica podrazumijeva legitimitet, odnosno prihvaćenost njenih osnovnih pretpostavki od većine građana. Dakle ne radi se o pukom poštivanju partikularnih propisa, nego aktivnom odnosu građanina kao pripadnika političke zajednice prema legislativnoj i političkoj sferi - to je pravo da pojedine političke odluke odobrava ili ne, da ima pozitivan ili negativan odnos prema političkim institucijama, da javno postavlja političke zahtjeve itd. Michal Sládeček, Pojmovno određenje političke zajednice, Filozofija i društvo XIX-XX, Institut za filozofiju i društvenu teoriju, Beograd, 2001.-2002., str. 181-182.

${ }^{4}$ Rita Floyd, Security and the Environment: Securitisation Theory and US Environmental Security Policy, Cambridge University Press, 2010, Review by: Oluwaseun Bamidele1, Theory in Action, Vol. 6, No. 1, January 2013, str.139. 
ba može doći od sekuritizatora, koji sekuritizaciju može iskoristiti za manipulaciju javnosti; od slušateljstva, koje može potencijal javno afirmiranog pitanja reartikulirati i dati mu smjer koji sekuritizator nije želio; od subjekta koji normativno i proceduralno definira sekuritizirano pitanje, a to je država. Postavlja se pitanje: tko u takvim uvjetima može dati tu objektivnu komponentu? To su u konačnici ipak slušateljstvo i država. ${ }^{5}$

$\mathrm{Na}$ taj način, neovisno o inicijatoru sekuritizacije: bio to pojedinac, društvena skupina (nedržavni akter) ili sama država, dobivamo uključenost cjelokupne političke zajednice (political community) i države. Vladimir Vujčić naglašava kako postoji opće slaganje teoretičara političkog sustava da je politička potpora građana nužna za stabilno i efikasno funkcioniranje političkog sustava u cjelini (Vujičić, 2008.:107). Slijedom te tvrdnje potpora građana i sinergija građana i države također je potrebna i za efikasno funkcioniranje političkog sustava u dijelu sigurnosnih pitanja, dakle i sekuritizacije. Tako definiran odnos građana i države u analizi procesa sekuritizacije olakšava odgovor na pitanje gdje proces sekuritizacije završava. Analiza modela Kopenhaške škole sugerira kako se sadržaj procesa sekuritizacije iscrpljuje s transformacijom određenog pitanja u sigurnosno pitanje. Međutim to istodobno ne bi bilo dovoljno za postizanje punog smisla sekuritizacije. Za puni sadržaj sekuritizacije potrebno je izvršiti normativni tretman sekuritiziranog pitanja koji će dati uporište za definiranje procesa i uspostavu/transformaciju prakse, a kroz koje će se sekuritizirano pitanje/problem kao takvo i zaštititi. Floyd navodi kako "pojedinac nije u poziciji da sam osigura svoju sigurnost. Stoga, logično, pružanje sigurnosti može biti zajamčeno samo od strane većeg entiteta, kao što su društvo, država ili neka globalna institucija“ (Floyd, 2007.:40). Buzan i Weaver ne dovode u pitanje dominantnu ulogu države u procesu sekuritizacije te ističu kako su u demokratskim državama vlade glavni skrbnici sigurnosti, odnosno birači im daju mandat i za tu funkciju. Međutim sve se više naglasak stavlja na civilno društvo i doprinos nevladinih organizacija u procesu sekuritizacije, pa tako i sekuritizaciji okoliša. No također valja istaknuti kako neki teoretičari drže da teorija sekuritizacije ne ispunjava sve zahtjeve za sigurnosnom kontekstualizacijom okoliša (Biswas, 2011.). Sigurnosna kontekstualizacija okoliša izvediva je kroz kombiniranje ili spajanje različitih pristupa koji na koherentniji način povezuju okoliš i sigurnost, „sekuritizacija nije govorni akt nego multidimenzionalni proces koji uključuje razne vještine. Ekspertsko znanje, institucionalna praksa i diskursi opasnosti moduliraju odnos sigurnosti i slobode" (Huysmans, 2006.:153).

Jedna od najčešćih zamjerki Kopenhaškoj školi i teoriji sekuritizacije nedostatak je preventivnih sigurnosnih instrumenata. Ističe se da nakon prebacivanja odrecene pojave u sigurnosni diskurs, sustav vrijednosti u svojoj biti počinje funkcionirati kao u konfrontacijskim situacijama ili onima karakterističnim za izvanredna stanja. Ipak valja naglasiti da se postavke Kopenhaške škole ne odbacuju u cijelosti, već je riječ

5 Država objektivnu komponentu daje kroz diobu vlasti, koja u normativnom procesu kroz predstavničko tijelo i javnu raspravu, koja se u normativnim procesima otvara, daje mogućnost objektivne evaluacije, odnosno kvantifikacije određenog pitanja kao sigurnosnog. 
o dekonstrukciji onog dijela koji se odnosi na praktično djelovanje u izvanrednim situacijama, potencijalno opasno za razvoj demokracije. Tako se, primjerice, razlikuju „pravila upravljanja i pravila mijenjanja“. Sekuritizacija afirmira pravila mijenjanja i naziva ih još refleksivnom sekuritizacijom (Beck, 1994.). Riječ je zapravo o kritici funkcioniranja suvremenih država koje nemaju politike preveniranja opasnosti po okoliš, već se u pravilu ograničavaju na naknadnu reakciju, odnosno zadržavaju se u sferi refleksivne sekuritizacije. Beck smatra da, čak i ako postoje različita gledišta o pojmu sigurnosti okoliša, sekuritizacija mnoštva problema koji se tiču zaštite okoliša vodi prema hitnim mjerama primjerenim rješavanju izvanrednih situacija. Stoga ne vidi u tome rješenje, već ga traži u sustavnom radu na podizanju globalne svijesti o očuvanju okoliša. Ovo razmišljanje o sigurnosti okoliša podrazumijeva širu transformaciju mišljenja naglašavajući kako rasprave o prevenciji, kao i stručne debate o očuvanju okoliša, već prilično jasno definiraju sigurnosni karakter svih problema s okolišem.

Teoretičari Kopenhaške škole teoriju sekuritizacije nadopunili su teorijom desekuritizacije kao svojevrsnom „dijalektičkom“ nadopunom sekuritizacije koja se definira kao sustav dugoročnih opcija (Hansen, 2012.). Riječ je o nastojanju autora da se uočene poteškoće sekuritizacije prevladaju i da se pokuša uspostaviti precizniji odnos prema dvojbama oko „izbacivanja“ određene pojave iz sfere sigurnosti. Teorijom desekuritizacije željelo se omogućiti napuštanje refleksivne sfere i analize sigurnosnog problema u političkoj, odnosno preventivnoj sferi. Ovdje je riječ o obrnutom procesu u odnosu na metodologiju sekuritizacije kojim se sigurnosna prijetnja definira tako što se težina potencijalnih opasnosti propituje i premještaja iz sfere hitnog djelovanja u polje uobičajene rutinske političke rasprave.

Desekuritizacija ima tri faze. Najprije dolazi do reakcije i kroz raspravu u javnosti uočava se svrhovitost promjene diskursa. Zatim ono što je pretpostavljeno kao prijetnja sada postaje problem koji se, možemo reći, vraća u sektor normalne politike. Naposljetku se odbacuju mjere primjerene izvanrednom stanju i izlazi se iz „carstva politike panike“. Ostavlja se mogućnost odustajanja od hitnih mjera i bez javne debate te se problem može rješavati u okviru političkih institucija zato što su argumenti koji govore u prilog odustajanja od hitnih mjera bili dovoljno uvjerljivi (Bonacker, Braun i Groth, 2009.).

Da bi se razumjela Waeverova konstrukcija, važno je naglasiti kako u ovom slučaju trenutačna sigurnost ne znači i trajno odsustvo nesigurnosti. Nadalje, nesigurnost je situacija u kojoj postoji prijetnja, ali ne i obrambeni potencijal, dok je sigurnost prisutnost prijetnje, ali i uspostavljen obrambeni mehanizam. Veza sigurnost - nesigurnost neodvojiva je od veze prijetnja - obrana i povećanje stupnja sigurnosti ne znači manje nesigurnosti. Jedini način da se izbjegne veza prijetnja - obrana jest desekuritizacija, ili odustajanje od sekuritizacije (Floyd, 2008.). Huysman smatra kako je teorija desekuritizacije manjkava jer i dalje ostaje dominantno u okvirima tehničke, menadžerske i instrumentalne razine, umjesto da napravi značajan iskorak u političko ili etičko (Huysmans, 1998.). Dakle ne izlazi iz instrumentalnog menadžerskog okvira i ne pronalazi uporište u političkom i etičkom. Toj kritici pri- 
družili su se Rita Floyd i Claudia Ardau 6 , koje također smatraju da je desekuritizacija nedovršena i podložna različitim interpretacijama. Analitički i politički je dvojbena zbog nedovoljnog akcenta na političko u sekuritizaciji kao konceptualnom prethodniku. Zamjera se nedovoljna jasnoća sekuritizacije i desekuritizacije kada govori o društveno odgovornom ponašanju kao ključnoj pretpostavci očuvanja okoliša, što za sobom povlači i druge sigurnosne implikacije. Nadalje, Kopenhaškoj školi spočitava se nekonzistentnost, odnosno utjecaj autora čije je viđenje politike i političkog često ne samo različito nego i posve suprotstavljeno. Floyd navodi kako Kopenhaška škola nije dovoljno jasna u smislu svog teorijskog uporišta te kako u stvari teži svojevrsnom derivatu promišljanja različitih teoretičara kao što su Arendt, Easton, Schmitt i Habermans, kao i Max Weber, Erneato Laclau, čije su postavke površno raspravljene (Hansen, 2012.:527).

\section{Sekuritizacija pitanja okoliša u ustavnim demokracijama}

Bez obzira na interpretacije i razmimoilaženja oko teorijskih postavki sekuritizacije i desekuritizacije, nedvojbeno je kako danas problemi zagađenja i uništavanja okoliša imaju presudnu ulogu u ljudskoj egzistenciji, što je i sankcionirano u nacionalnim i međunarodnim pravnim aktima. Rasprave tijekom zadnjeg desetljeća 20. stoljeća apsolvirale su ovo pitanje, od toga koliko degradacija okoliša može generirati međunacionalne sukobe do opasnosti za svjetsku populaciju koje donosi nekontrolirani industrijski razvoj. Nema više dvojbi oko toga je li riječ o pitanjima sigurnosti, kako nacionalne tako i međunarodne. Razvijene države deklarativno rade na podizanju svijesti o potrebi kontinuiranog unapređivanja mjera za zaštitu okoliša. U ekonomskoj sferi javni je diskurs nezamisliv bez sintagme - ekološki održivi razvoj, i na prvi pogled može se činiti kako je Beckova kritika sekuritizacije kao „refleksivne teorije“ iz sredine 90-ih uglavnom prevladana. Naime zaštita okoliša danas je ugrađena u ustave svih razvijenih država svijeta, kao što sve moderne države u svojim strategijama nacionalne sigurnosti zaštitu okoliša stavljaju uz bok, primjerice, protuterorističkim aktivnostima ili borbi protiv organiziranog kriminala. Dakle može se zaključiti da je zaštita okoliša konzekventno sekuritizirana, odnosno sve što se događa suprotno tome tretira se kao eksces podložan sankcioniranju.

No unatoč tome međunarodne konvencije, multilateralni i bilateralni sporazumi nisu zaustavili napetosti kada se u stručnoj i političkoj javnosti raspravlja o ugroženosti okoliša. Međunarodne institucije zajedno s ekološkim nevladinim udrugama i predstavnicima znanstvene zajednice u javnom prostoru, na globalnoj i lokalnoj razini, nastupaju s alarmantnim prognozama. Primjerice, neke od poruka s godišnjeg zasjedanja Svjetskog gospodarskog foruma u Davosu u siječnju 2015. godine bile su alarmantne. Ban Ki-moon, generalni tajnik UN-a, označio je 2015. godinu kao prijelomnu kada je riječ o borbi protiv siromaštva i gladi, kao i očuvanju okoliša na Zemlji kao glavnom preduvjetu te borbe. Mnogi svjetski uglednici poslali su iz

6 Floyd, „Towards a Consequentialist Evaluation“, 330-335.; Ardau, „Security and the Democratic Scene", 389-90 
Davosa slične poruke. ${ }^{7}$ Predstavnici znanstvene zajednice bili su još radikalniji upozoravajući da liberalni kapitalizam i razarajuća globalizirana ekonomija vode Zemlju u propast. Zapravo iz Davosa se nije čulo ništa što bi predstavljalo neku posebnu novost, odnosno može se reći kako se očuvanje okoliša konstantno „resekuritizira“, ali se problem ne rješava. Takve i slične javne poruke nameću ponovno preispitivanje teze o refleksivnoj biti sekuritizacije. Kao da i dalje samo označavamo problem kao sigurnosni kako bi se onda odredile mjere za djelovanje te kao da nema previše praktičnih napora za rješavanje daleko značajnijih izazova koji impliciraju korjenite promjene u načinu života i proizvodnje (Trombetta, 2007.). No je li uopće moguć radikalni zaokret u načinu života i proizvodnje?

Uloga država i vladinih međunarodnih organizacija, kao dominantnih subjekata u procesu sekuritizacije, odnosno desekuritizacije, dvojbena je ili u najmanju ruku nedostatna budući da svjedočimo kršenju svih onih normi ugrađenih u nacionalna i međunarodna zakonodavstva i strateške dokumente visokorazvijenih država.

Moderna ekonomija izuzetno je moćna, a tu moć zahvaljuje neovisnoj društvenoj poziciji i ubrzanom tehnološkom razvoju. Predmoderna društva morala su se dominantno usredotočiti na zaštitu poretka i sigurnosti, dok je proizvodnja dobara bila oskudna i u drugom planu, pa su političke i religijske organizacije ostvarivale dominaciju nad svim ekonomskim elementima (Gellner, 2001.:152). O početku moderne ekonomije u Engleskoj u 18. stoljeću Gellner kaže kako je postojala dobra društvena infrastruktura i ravnoteža moći tako da se tržište moglo nesmetano razvijati. Tehnologija je bila dovoljno moćna da osigura napredak, ali ne i toliko da bi uništila društvo i okoliš. Danas su, naravno, okolnosti bitno izmijenjene, moderna tehnologija ima ogromnu moć i nerijetko je pogubna za okoliš. Međutim, kako Gellner ističe, „glomazna društvena infrastruktura danas čini nužnim da veliki dio ukupnog proizvoda visokorazvijenih zemalja kontroliraju političke institucije“ (Gellner, 2001.:152). Uspješna gospodarstava jesu ona gdje je država sposobna napraviti „tihi pakt“ s neovisnim proizvođačima. O predmodernim društvima Gellner, dakle, razmišlja kao o zajednicama gdje su politička pitanja bila znatno važnija, a tržišno društvo nije bilo moguće jer je gospodarstvo bilo preslabo. Kako kaže, „umiranje od gladi moralo se spriječiti politički i jedino se tako moglo, ako se uopće moglo“. U tim uvjetima oslobađanje tržišta od političkog nadzora bilo bi pogubno, dok danas, kao i u budućnosti, potpuno slobodno tržište bit će nemoguće iz posve suprotnih razloga - zato što je gospodarstvo nevjerojatno moćno. Stoga je potreban politički nadzor na njim jer će u suprotnom uništiti sve - okoliš, kulturnu baštinu, međuljudske odnose (Gellner, 2001.:153). Državni nadzor mora biti diskretan i konsensualan kao proizvod pregovora, odnosno kako Gellner zaključuje, gospodarstvo mora biti dovoljno slobodno da omogući pluralne institucije s njihovim bazama, ali ne toliko moćno da uništi naš svijet.

No je li danas država u tom smislu prediskretna? Koliko je nadzor koji trebaju obavljati političke institucije temeljen na pregovorima? U razvijenim kapitalističkim

${ }^{7}$ Cjelokupno izvješće s izlaganjima svih sudionika dostupno je na stranicama World Economic Foruma, https:// agenda.weforum.org, uvid izvršen 10. veljače. 
društvima predstavnici političkih institucija nerijetko dolaze iz poslovnih struktura ili se pak nakon završenih mandata tamo vraćaju. Kontrola moćnih gospodarstava u takvim uvjetima ne može funkcionirati dobro, a državna financiranja različitih istraživanja i organizacija stručnih skupova, u pravilu s brojnim visokim izaslanicima kao što su šefovi država i premijeri, doimaju se kao umirivanje nečiste savjesti ili kao dobra marketinška strategija. Tako na scenu stupa civilno društvo koje osigurava veću participaciju građana (dakle istodobno podiže ljestvicu u razvoju demokracije) i bolju kontrolu. ${ }^{8}$ U strahu da oblici kontrole ekonomskih sustava lako mogu degenerirati u autoritarno gušenje ekonomske samostalnosti, Gellner tvrdi da je bolje početi s druge strane i pokušati naći neki benigni oblik političkog nadzora u moru zloćudnih te zaključuje „politički nadzor čija je protuteža samostalan niz proizvodnih jedinica nudi odgovor - da civilno društvo jest rješenje“. Dakle Gellner polaže velike nade u civilno društvo i vidi ga kao korektiv potencijalnoj neučinkovitosti države.

Uz određenu rezerviranost prema učinkovitom i objektivnom državnom nadzoru gospodarstava modernih industrijskih zemalja, tu zapravo dolazimo do ključnog pitanja - je li moguće i kako uspostaviti održivi rast gospodarstava s primjerenom kontrolom, a da ne budu ugroženi demokratski procesi? Gellner smatra da nadzor mora biti takav da se izbjegne ekološka katastrofa ili oskudica stanovništva, no po ispunjenju tih ciljeva nadzor bi morao biti „mnogo manje od potpunog“ (Gellner, 2001.:154).

Gellner kao polazište za razmišljanje o raznim koncepcijama i praksama civilnog društva uzima paradigmu „civilno društvo - pravna država“. U tom bipolarnom modelu civilno društvo podrazumijeva samoorganiziranje građana na osnovi dobrovoljnosti i zajedničkih interesa uz nenasilni model zastupanja interesa „u borbi za unapređenje kvalitete života na principima slobode, jednakosti, solidarnosti, pravde; za ostvarivanje principa konstitucionalne demokracije, za obranu socijalnih, političkih, ekonomskih prava od zloupotreba vlasti“ (Vujadinović, 2007.:22). Civilno društvo, odnosno njegova praksa dio je polja politike, kako kaže Vujadinović, u širem smislu. To je, dakle, mehanizam kontrole nositelja političke vlasti, političkih stranaka na vlasti i opoziciji koje spadaju u polje politike u užem smislu. ${ }^{9}$ Uloga civilnog društva označena je kao mobilizatorska kada je riječ o građanskim interesima, borbi za politička i socijalna prava na temelju slobode jednakosti, pravde, promicanja demokratske političke kulture solidarnosti, pluralizma, tolerancije, nenasilja i humanizma. Vujadinović ističe šest glavnih pretpostavki za postojanje civilnog društva: 1. pravna država; 2. zajamčena osnovna građanska, politička socioekonomska prava i

8 U ovom slučaju pod pojmom civilnog društva podrazumijevamo razne nevladine organizacije koje se bave promicanjem zaštite okoliša.

9 Vujadinović naglašava kako postoje određene dileme i rasprave oko kriterija za definiranje što pripada pojmu civilnog društva te ističe kako neutralno definirani pojam civilnog društva u sebi uključuje i ekstremno desničarske i općenito ekstremističke društvene pokrete, građanske inicijative i nevladine organizacije. Prema njezinom mišljenju na takav način gubi se normativno-mobilizatorska dimenzija civilnog društva, koja je u funkciji „unaprjeđenja, kontrole, komplemenata konstitucionalne demokracije“. 
slobode; 3. proceduralna demokratska pravila i institucije; 4. tržišna ekonomija; 5. demokratska politička kultura; 6. participacija građana, aktivizam u kreiranju kritičke javnosti i samoorganiziranju za obranu ugroženih prava (Vujadinović, 2008.:24).

Unatoč ovako definiranoj ulozi civilnog društva u ustavnim demokracijama neki teoretičari, osim što se slažu oko njegova generalno pozitivnog doprinosa demokratskom razvoju, ističu kritička razmišljanja o idealiziranoj slici civilnog društva kao oblika organiziranja i komunikacije građana koji unapređuju demokratske procese (Reese-Schäfer, 2004.). Tako, primjerice, Reese-Schäfer tvrdi da je civilno društvo nedvojbeno važno za demokraciju, ali su istodobno nužni mehanizmi njegova ograničenja. Kada govori o lošim stranama organizacija civilnog društva, ističe sklonost blokadama reformi, opasnosti od gubitka primarne uloge u različitim populističkim pokretima i socijalnoj asimetričnosti građanskog aktivizma. Reese-Schäfer definira i vrijednosnu orijentaciju civilnog društva smatrajući da je u Europi i SAD-u koncept nevladinog sektora dobio zamah zbog toga što su lijevo orijentirane organizacije došle u situaciju u kojoj su morale početi tražiti novo, šire samorazumijevanje. Ističe da je tematska heterogenost ekološkog pokreta i antiraketnog pokreta trebala „otvoreniji i širi oblik legitimacije“ (Reese-Schäfer, 2004.:74). Slično kao i Gellner, smatra da je značajan doprinos civilnog društva unaprjeđivanju demokratskih procesa u mrežnom strukturiranju i utemeljenju društvenog sklopa kako se državi i privredi ne bi dopustilo da postanu jedine dominirajuće snage (Reese-Schäfer, 2004.:66).

Ustavne demokracije nedvojbeno su danas nezamislive bez djelovanja mehanizama civilnog društva, a interakcija s predstavnicima političke vlasti značajno je obilježena političkom kulturom. Prisutnost demokratske političke kulture ima presudan značaj za razvoj civilnog društva, kao što je nedemokratska politička kultura jedna od najznačajnijih prepreka za njegov razvoj (Vujadinović, 2008.:31), pa je stoga legitimno propitivanje vrijednosnih orijentacija ekoloških nevladinih udruga kao prominentnih predstavnika civilnog društva.

\section{Vrijednosna orijentacija i dometi ekoloških nevladinih udruga u sekuritizaciji okoliša}

Valja se zapitati kakve su i kolike mogućnosti civilnog društva kao protuteža političkim strukturama i moćnim privredama? Postavljaju li pred njih Gellner i ReeseSchäfer pretežak zadatak? Možda je ipak utopijski razmišljati o strukturama civilnog društva kao, slikovito rečeno, povratku demosa u polis nakon što je bio u izgnanstvu, premda se nevladine organizacije sve češce i artikuliranije pojavljuju na javnoj sceni. Razvoj novih medija olakšava im djelovanje, a sami članovi sve su educiraniji. Ipak, dometi nadzora nad državom i privredom kao dominirajućim snagama nisu osobiti. Naime kontekst u kojem se odvija pokušaj utjecaja na politiku i ekonomiju, kako bi se efikasno štitio okoliš, ne ide u prilog civilnom društvu. Primjerice, UNova Organizacija za hranu i poljoprivredu (FAO) 2008. godine objavila je podatke o milijardu stanovnika Zemlje koji gladuju, a za ublažavanje tog problema trebalo je izdvojiti 30 milijardi dolara. Iste godine središnje banke Sjedinjenih Država, EU-a, Japana, Kanade, Velike Britanije i Švicarske odlučile su u privatni posrnuli bankarski 
sektor svojih zemalja uložiti 180 milijardi dolara. Također, Senat SAD-a odobrio je dodatnih 700 milijardi dolara i dva tjedna nakon te odluke još 850 milijardi dolara. (Marković, Dragović Sekulić, 2013.:48). Premda svi posrtaji financijskog kapitalizma nemaju direktne veze s pitanjima okoliša i njegove zaštite, u mnogome oslikavaju duh vremena za koji se može ustvrditi da ne ide u prilog organizacijama civilnog društva, odnosno njihovoj utvrđenoj ulozi kontrolora političke vlasti i ekonomskih subjekata. Kada su suočeni s dilemom spašavati ljudske živote ili neodgovorne privatne banke, političari donose odluke koje idu u prilog financijskom elitama, što autore navodi na realističan zaključak: „Takav je svijet u kojem pokušavamo govoriti o zaštiti okoliša, zaboravljajući nevidljive veze između ekonomije i politike, mjestima i procesu donošenja odluka mimo, a često i protiv interesa građana“. Štoviše, mišljenja su da ne postoje učinkoviti mehanizmi kojima bi se poboljšala funkcionalnost odluka i sigurnost samih građana, koji su stiješnjeni između politike i ekonomije. Tako se moramo vratiti ishodišnom pitanju o mogućnostima djelovanja ekoloških pokreta i organizacija na osnovnoj instanci - verbalnom artikuliranju i označavanju problema, čemu teoretičari Kopenhaške škole posvećuju iznimnu pozornost.

S obzirom na brojnost, utjecaj i način djelovanja, potrebna je načelna klasifikacija ekoloških udruga. Istraživački radovi bave se ekološkim udrugama i organizacijama ovisno o tome jesu li orijentirane na globalno djelovanje ili su isključivo dio lokalne sredine, zatim je li riječ o aktivističkim pokretima ili profesionalnim organizacijama s jasnom strukturom, hijerarhijom i proračunom. Tako možemo govoriti o takozvanim „odvjetničkim ekološkim organizacijama“, koje nastoje djelovati na politički proces i formiranje političke agende, nastoje informirati javnost o određenim planovima političkih institucija, skupljaju informacije raznih znanstvenih institucija, međunarodnih organizacija ili državnih agencija i u javnom prostoru djeluju kao posrednici ili tumači znanstvene zajednice. Reagiraju brzo na svaku incidentnu situaciju kako bi skrenuli pozornost javnosti i ubrzali političko djelovanje prema postizanju rješenja. S druge su strane „servisne ekološke organizacije“, koje surađuju s institucijama i nude volonterske savjetničke usluge ili su plaćene za rad u međunarodnim organizacijama ili nacionalnim vladama. ${ }^{10}$ Međutim u ovom nas slučaju prvenstveno zanima vrijednosni sustav ekoloških organizacija i pokreta, odnosno tip političke kulture ${ }^{11}$ iz

10 Širi pregled pogledati u Environmental NGO's in Emerging Global Civil Society, Helmut Breitmeier, Volker Rittberger, Center for International Relations University of Tübingen (http// www.uni-tubingen.de/uni/spi/taps/tap32.htm, uvid izvršen 26. siječnja 2015).

11 Sam pojam političke kulture ima široko određenje. Podjele mogu biti na osnovi vrijednosne orijentacije na modernost, budućnost, razvoj i napredak nasuprot nastojanjima u očuvanju tradicije, naslijeđa prošlosti, ustanovljenog državnog i društvenog poretka, a u kombinaciji s tipom odnosa demokratskih/egalitarnih ili hijerarhijskih/autoritarnih, može se smatrati kao analitički produktivna crta razgraničenja tipova političkih kultura (Vujadinović, 2008.:31). Autorica ispravno zapaža i to da je polje političke kulture, kao i svih modernih društvenih procesa, uvijek i medij konfrontacije tradicionalizma i modernizacijskih procesa, tradicionalne i demokratske političke kulture, te da je riječ o kompleksnom prostoru susretanja „pluralizma kulturnih, normativnih i političkih obrazaca, kvantitativnih i kvalitativnih promjena unutar svakog ispoljavanja političke kulture, kao i međuodnosu - odnosu prevaga, dominacije, borbe za prevlast različitih modaliteta i civilizacijskih tendencija na polju političke kulture". 
kojega su izrasli i javno nastupaju. Repertoar akcija koje stoje na raspolaganju ekološkim pokretima i organizacijama čvrsto je povezan s karakterom uspostavljenih političkih institucija u određenoj sredini i političkom kulturom koja se u njoj razvija (Carmin, 1999.:3).

U tom kontekstu zanimljivo je analizirati nekoliko recentnijih slučajeva pokušaja sekuritizacije određenih ekoloških pitanja u Hrvatskoj. Svi su slučajevi izazvali priličnu medijsku pozornost. Nakon što su označeni kao poželjne investicije koje dovode do stvaranja novih radnih mjesta, uslijedila su žestoka protivljenja i prosvjedi ekoloških udruga. Riječ je o termoelektrani Ploče (1,2 milijarde eura), odlagalištu otpada Marišićina pokraj Rijeke (101,6 milijuna eura), hidroelektrani Ombla (154 milijuna eura), Plomin C u Istri (850 milijuna eura), hotelu Palace u Kaštelima (200 milijuna eura), proširenju ACI marine u Dubrovniku, istraživanju nafte u Jadranu (više milijardi eura). ${ }^{12}$ Možda je najilustrativniji primjer istraživanje nafte u Jadranu, projekt koji su predstavnici političkih institucija označili kao najprofitabilniji. Raspisan je natječaj za dodjeljivanje koncesije, na što su reagirale ekološke udruge Zelena akcija i Eko Kvarner zahtijevajući hitnu sjednicu Sabora s temom istraživanja Jadrana i najavivši inicijativu za raspisivanje referenduma o zabrani cijelog projekta zbog opasnosti za okoliš. Stranka OraH, koja u svom programu promovira ekološki održiv razvoj i koja je na izborima za Europski parlament dobila jednog zastupnika, istovremeno je na stanoviti način pitanje istraživanja nafte u Jadranu desekuritizirala, vratila u sferu politike. Upozorili su na određene proceduralne nelogičnosti, odnosno stranka, između ostaloga, smatra da je u ovom slučaju primarno napravljena proceduralna pogreška, odnosno da je vlada raspisala natječaj prije nego što je napravljena procjena održivosti cijelog projekta. S jedne strane ekološki aktivisti (također su isticali i proceduralne nelogičnosti) od političkih predstavnika ultimativno traže uspostavljanje žurnih mjera vršeći javni pritisak kako bi se projekt suspendirao zbog rizika od štetnih utjecaja na okoliš, dok parlamentarna stranka OraH smatra da je javnu raspravu i raspisivanje natječaja trebalo pokrenuti nakon studije izvedivosti, iako upozoravaju da bi istraživanja Jadrana mogla biti potencijalno opasna za okoliš. Istaknuli su, osim toga, da je sve napravljeno suprotno direktivi EU-a iz 2013. godine donesenoj nakon ekološke katastrofe izlijevanja nafte u Meksičkom zaljevu te Arhaškoj konvenciji, ${ }^{13}$ koja traži da se javnost upozna sa svim detaljima utjecaja na okoliš prije raspisivanja natječaja i dodjeljivanja koncesije. U OraH-u su još istaknuli da se ne protive istraživanju, ali tek kada svi elementi projekta budu poznati. Kao parlamentarnoj stranci važno im je bilo da na komunikacijskoj razini otklone moguće razumijevanje njihove pozicije kao opstrukcionističke. Politička stranka djeluje unutar institucionalnih okvira i stavlja naglasak na proceduru, javna rasprava - odluka, što znači da ide putem postupne desekuritizacije, dok aktivisti djeluju naglašeno sekuritizatorski, odnosno u javnom prostoru komuniciraju na osnovi paradigme okoliša kao sigurnosnog pitanja.

12 Večernji list, Zbog borova blokirana gradnja hotela, a zbog šišmiša - hidroelektrana, 6. veljače 2015.

13 no svim direktivama, 16. siječnja 2015. 


\section{Zaključak}

Nakon sloma komunističkih režima 90-ih godina prošlog stoljeća postupno se počinje mijenjati pristup definiranju i proučavanju sigurnosti. Blokovski državocentrični pojmovi sigurnosti koji su za ishodište uzimali vojnu prijetnju državnoj sigurnosti postali su preuski te je nastupilo razdoblje redefiniranja tog pojma. Tako je interes stručne javnosti pomaknut prema teoriji sekuritizacije i desekuritizacije Kopenhaške škole nastale nekoliko godina ranije. Istodobno s intenziviranjem industrijskog razvoja bilježi se sve više negativnih posljedica na cjelokupni ekosustav. Kada je riječ o okolišu, u sklopu sigurnosnih studija početkom 90-ih dominirale su dvije vrste rasprava. Prvo, koliko je teorijski okvir što su ga razvili vodeći teoretičari Kopenhaške škole adekvatan u sekuritizaciji problema ugroženog ekosustava i drugo, pripada li degradacija okoliša sferi nacionalne sigurnosti. Međutim eksploatacija prirodnih resursa kao i udari na ekosustav potisnuli su ove rasprave u drugi plan, a zaštita okoliša postaje globalni sigurnosni fenomen koji zahtjeva globalnu institucionaliziranu akciju.

Nakon 90-ih intenzivira se razvoj civilnog društva kao „trećeg sektora“ koji se pozicionira između jake ekonomije i političke vlasti. Civilno društvo otvara mogućnost masovnije političke participacije građana u državama razvijenog neoliberalnog kapitalizma i predstavničke demokracije, koje su počele pokazivati svoje prve nedostatke i prije velike ekonomske krize 2007. godine. Međunarodna zajednica ne uspijeva to pitanje riješiti na temelju međunarodnog prava, iako su zemlje članice UN-a pokušavale pronaći rješenje još od sredine 90-ih i Protokola iz Kyota. Političke institucije nerijetko su u podčinjenom položaju u odnosu na snažne ekonomske aktere, pa je logično da ekološke aktivističke organizacije civilnog društva nastoje stvoriti prostor za snažnije djelovanje i preuzeti ulogu sekuritizatora. U pravilu zahtijevaju uspostavljanje žurnih mjera zbog ugrožene sigurnosti, bilo da je riječ o lokalnom ili globalnom fenomenu. Ekološki aktivisti brži su i pokretniji u odnosu na birokraciju međunarodnih i državnih institucija, ali zbog naglašene sekuritizatorske pozicije mogu postati zatvoreni za rasprave. Politička kultura oponiranja svojstvena je ekološkim aktivistima, ali to i ne znači nužno opstrukcionistički i loš utjecaj na demokratske procese. Oni su naprosto vrijednosno bliže onoj vrsti konzervativizma koji je oprezan prema promjenama te su, kako Reese-Schäfer ističe, potrebni „filtri primjereni tom ponašanju koji bi mogli držati na uzdi proizvoljne zahtjeve organiziranih posebnih interesnih grupa“. No što sve te karakteristike civilnog društva na temelju kojih se govori o „petom stupu demokracije“ ili, suprotno, o „najprecjenjenijim političkim akterima današnjice“ znače u kontekstu zaštite okoliša? Što ako političke institucije budu i dalje nedovoljno djelotvorne u obuzdavanju nositelja ekonomskog razvoja, a civilno društvo ostane na pozicijama protivljenja tom razvoju, čak ako ono i nema direktnih i značajnijih utjecaja na eroziju okoliša? Ta su pitanja, nažalost, vrlo kompleksna i na njih ne postoji jedan jedini ispravni odgovor. Potrebna je veća odgovornost političkih elita, dok aktivizam mora biti fokusiran na otklanjanje manjkavosti koje im priječe da budu vjerodostojan akter u procesu sekuritizacije. I jedni i drugi, političke institucije i civilno društvo, imaju svoje neizostavne uloge, bez obzira na to jesu li u konfrontacijskom ili pregovaračkom odnosu. Bez interakcije, ma kakva ona bila, pitanje zaštite okoliša bilo bi još problematičnije. Stoga se ne smije gubiti vjera, bilo u demokraciju bilo u participativni potencijal civilnog društva. 


\section{Literatura}

1. Beck, U. (1994). The Reinvention of Politics: Towards a Theory of Reflexive Modernization, u: Beck, U.; Giddens, A. and Lash, S. (Eds.). Reflexive Modernization: Politics, Tradition and Aesthetics in the Modern Social Order. Cambridge: Polity, 1-55.

2. Bereitmeier H. and Rittberger V. (2000). Environmental NGO's in an Emerging Global Civil Society. Center for International Relations, University of Tübingen. http://www.uni-tibingen.de/uni/spi/taps/tap32.htm (1-29).

3. Biswas, N. R. (2011). Is the Environment a Security Threat? Rational Environmental Security beyond Securitization. International Affairs Review, xx (1). The Elliot School of International Affairs at George Washington University.

4. Bonacker, T.; Braun, C. and Groth, J. (2009). The Impact of Civil Society's Human Rights Articulations on Securitization in Ethno-Political Conflicts. A Qualitative Comparative Analysis, SHUR Working Paper Series 02/09. University of Marburg, Center for Conflict Studies.

5. Buzan, B., Waever, O. and de Wilde, J. (1998). Security: A New Framework for Analysis. Boulder Co: Lynne Rienner.

6. Carmin J. (1999). Voluntary Associations, profesional Organizations, and the environmental Movement in the Unuted States. Environmental Politics, 8 (1): 101-121.

7. Collins, A. (2007). Contemporary Security Studies. Oxford University Press.

8. Deudney, D. (1990). The Case Against Linking Environmental Degradation and National Security. Millennium-Journal of International Studies, 19: 461-476.

9. Homer-Dixon, T. (1999). Environment, Scarcity, and Violance. Princeton: Princeton University Press.

10. Edkins, J. (1999). Poststructuralism and International Relations: Bringing the Political Back In, Critical Perspectives on World Politics. Boulder Co: Lynne Rienner Publishers.

11. Floyd, R. (2007). Human Security and the Copenhagen School's Securitization Aproach: Conceptualizing Human Security as a Securitizing Move. Human Security Journal, 5: 38-49.

12. Floyd, R. (2008). Environmental Security Debate and Its Significance for Climate Change. International Spectator, 43 (3): 51-65.

13. Floyd, R. (2010). Security and the Environment: Securitisation Theory and US Environmental Security Policy. Cambridge: Cambridge University Press.

14. Floyd, R. and Croft, S. (2010). European non - traditional security theory, EUGrasp Working Papers, Working Paper No 1, February 2010.

15. Freeden, M. (1998). Ideologies and Political Theory-Aconceptual Approach. Oxford: Clarendon Press.

16. Gellner, E. (2001). Uvjeti slobode, civilno društvo i njegovi suparnici. Zagreb: Politička kultura.

17. Hansen, L. (2012). Reconstructing desecuritisation: the normative-political in the Copenhagen School and directions for how to apply it. Review of International Studies, 38 (3): 525-546.

18. Hoekstra, J. (2014). Networking Nature- How Technology is Transforming Conservation. Foreign Affairs, 93 (2). 
19. Hough, P. (2004). Understanding Global Security. London: Routledge.

20. Huysmans, J. (1998). The Question of the Limit: Desecuritisation and the Aesthetics of Horror in Political Realism. Millennium - Journal of International Studies, 27: 569-589.

21. Kahl,C. H. (2008). States, Scarcity and Civil Strife in the Developing World. New Jersey: Princeton University Press.

22. Kaplan, R. D. (1994). The coming anarchy. The Atlantic Montbly, February1994.

23. Levy, M. A. (1995). Is The Environment a National Security Issue. International Security, 20 (2): 35-62.

24. Marković I. S. i Dragović Sekulić S. (2014). Ekologija između politike i ekonmomije. Informatol, 47 (1): 46-51.

25. Mayers, N. (1989). Environment and Security. Foreign Policy, 74: 23-41.

26. Peluso, N. L. and Watts, M. (2003). Violent Environments: Responses, Environmental Change and Security Project Report no. 9. Woodrow Wilson Center, Washington D.C.: 93-6.

27. Reese-Schäfer, W. (2004). Civilno društvo i demokracija. Politička misao, XLI (3): $65-79$.

28. Shorr, D. (2014). Think Again: Climate Treaties. Foreign Policy, (March/April 2014.)

29. Sládeček, M. (2002). Pojmovno određenje političke zajednice. Filozofija $i$ društvo, XIX-XX: 179-191.

30. Snow, D. M. (2007). National Security for a new Era-Globalization and Geopolitics. New York: Pearson \& Longman.

31. Trombetta, M. J. (2007). The Securitization of the Environment and the Transformation of Security, (draft). Delft University of Tehnology. http://www.eisa-net. org/be-bruga/eisa/files/events/turin/Trombetta-the_securitization_of the_environment and the transformation of security.pdf.

32. Ullman, R. H. (1983). Redefining Security. International Security, 8 (1): 129-153.

33. Vilijams, P. D. (2012). Uvod u studije bezbednosti. Beograd: JP Službeni glasnik.

34. Vujadinović D. (2007). Civilno društvo i politička kultura. Filozofska istraživanja, 109 (god.28, Sv.1). 21-33.

35. Vujčić, V. (2008). Kultura i politika. Zagreb: Politička kultura.

36. Wolfers, A. (1962). Discord and Collaboration: Essays on International Politics. Baltimore: Johns Hopkins University Press. 
Pregledni rad

Dario Malnar

Zagreb, Croatia

e-mail:malnar.zg@gmail.com

Vedran Matošić

Zagreb, Croatia

e-mail:vedranmatosic@gmail.com

\title{
Environmental Security - Between Activism and Securatization
}

\begin{abstract}
Approaches to the study and definition of the concept of security have started to change rapidly since the end of the Cold War. Today there is a high level of agreement among theorists that security is a dynamic social process, hence threats to security are different, not necessarily defined as military threats to national sovereignty. The definition of a security threat depends on the time and place. One of the most important contributors to the study of the contemporary phenomenon of security is the Copenhagen school of security studies. Buzan, Waever and associates have established the theory of securitization and desecuritization as a persuasive instrument for defining contemporary security threats in the context of modern liberalism. Securitization marks a given phenomenon as a security threat and transfers it to the sphere of the so-called emergency action which is, according to the critics of the Copenhagen school, its major drawback since such situations may cause the erosion of democratic standards. Therefore, the theory of desecuritization tries to prevent securitization from potentially jeopardizing the democratic process. Specifically, emergency measures can be withdrawn without a public debate and the matter handed over to political institutions when and if the arguments in favor of withdrawal are sufficiently convincing. Regardless of different theoretical approaches, one can argue that the state still remains the most dominant actor in defining a specific problem as a security threat. When it comes to matters of environmental damage, civil society is emerging as a credible securitizator and corrective to state institutions which are often unable to adequately "control" levers of economic development. However, civil society also has certain limitations which are most commonly manifested in the blockage of reforms and social asymmetries of civic activism.
\end{abstract} ety. 